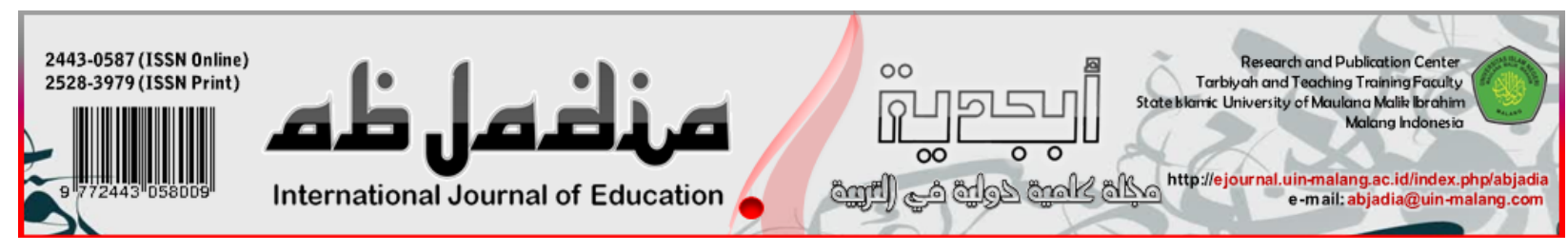

\title{
THE ANALYSIS ON FACTORS INFLUENCING THE LEARNING OUTCOME ON MICROECONOMICS USING CONFIRMATORY FACTOR ANALYSIS MODEL
}

\author{
Luthfiya Fathi Pusposari \\ Universitas Islam Negeri Maulana Malik Ibrahim Malang, Indonesia
}

\begin{abstract}
Article History:
Received : 2019-11-12

Revised : 2019-11-26

Accepted : 2019-12-05

Published : 2019-12-30
\end{abstract}

Keywords:

Learning Outcome, Microeconomics

Theories, Confirmatory Factor Analysis

Correspondence Address:

luthfiya@pips.uin-malang.ac.id

\begin{abstract}
The research aims to identify factors influencing the learning outcome on microeconomics theories of social education students of UIN Malang. Theoretically, factors influencing learning outcomes are varied. Therefore, the researcher collaborates some opinions on factors influencing learning outcomes, and the process generates 25 subfactors. The research employs a quantitative descriptive method. The data was collected using questionnaires of the Likert scale and distributed to all research subjects. The researcher employed a confirmatory analysis model to analyze the data. The result showed that there are seven factors influencing learning outcomes on the economy subject: 1). The ability of students and lecturer related to the element on background knowledge, teaching method, course interest, learning manner, lecturer's explanation; 2). The Learning method about student learning style, learning the habit, and determining intensity; 3). The Students' initial modal formed by factors such as previous experience, talent, benefit, and intelligence; 4). The variable of sex and age creates the readiness factor; $5)$. The facility factor formed by the variable of classroom facilities and the financial situation; 6). The moral condition and family support create the psychology factor; 7). The last element is learning drive is formed by the variable of recitation and motivation.
\end{abstract}

\section{(6) Introduction}

The industry revolution 4.0 leads to open competition in all fields; however, the fittest will survive. In the economic area, for instance, higher job vacancies become an obstacle for domestic job seekers. One indicator to determine the ability of job seekers is using their learning outcome. It is a written statement on someone's ability after completing a course or specific qualification (Adam, 2004). In Indonesia, the learning outcome confirmed using The Regulation of Minister of National Education Number 23 of 2005, stating that learning achievement in the aspect of knowledge and skill conducted in a well-planned and systematic way in the form of final evaluation and school/Islamic school examination.

The final scoring at the university level is reflected in Grade Point Average (GPA). Social Education of UIN Maulana Malik Ibrahim Malang has the same method. The GPA is equal, with the total point in all subjects divided with the full credits (TIM FITK, 2018). 
Nowadays, the job opportunity is open globally, and it demands that the students' GPA should be nearly the optimum point, which is 4.00 .

The curriculum distribution and mean GPA of second-semester Social education students can be seen in the following table.

Table 1: The Mean GPA of Second Semester Social Education Students
\begin{tabular}{|c|l|c|}
\hline No & \multicolumn{1}{|c|}{ Subject } & The mean GPA \\
\hline 1 & Introduction to Geography & 84.85 \\
\hline 2 & Developmental Psychology & 80.78 \\
\hline 3 & History of Indonesia & 81.74 \\
\hline 4 & Indonesian Language & 84.27 \\
\hline 5 & Microeconomics Theory & 77.71 \\
\hline
\end{tabular}
Data source: Siakad of Social Education Department (2018)

Based on the table, the subject of Microeconomics Theory contributed to the lowest point for the learning outcome (GPA). The researcher has conducted research related to learning outcomes showing that there is no significant influence on students' learning styles on the learning outcome of microeconomics theory. The value of $\mathrm{R}$ square shows that $1.9 \%$ was influenced by learning style, while the rest or $98.1 \%$ was influenced by other variables beyond the gained regression model (Pusposari, 2017).

Many types of research in Indonesia conducted on learning the outcome, such as (Sutrisno \& Siswanto, 2016), Nita (2017), in which the researchers determined to learn issues through the regression model by using 2-3 independent variables. Research on learning result using factor analysis was conducted by Kurniawan, in which the result showed that there are two factors influencing learning outcome, namely internal factor (interest, motivation, focus) and external factor (method, media, and social environment, and the most dominant factor is motivation (Kurniawan, Wiharna, \& Permana, 2017). Another research was done by Lin, which stated that the most dominant factor influencing learning outcome is the instruction (method and strategy) and personal reasoning ability (Lin, 2016).

Phenomena related to learning outcomes are widely varied. Based on the literature study conducted by Hattie, the total of concepts on the learning outcome itself is more than 50,000 (Hattie, J.A.C., 2009). Muhibbin Syah stated that there are three types of factors influencing student's learning achievement, namely "internal factor, an external factor, and learning approach factor." (Muhibbin Syah, 2017)

a. Internal factor (inside factor). It is a factor from an individual consisting of a student's physical and spiritual condition. The physical element is a general condition of the body and tonus (muscle tense), indicating the fitness level of its organs and joints, which may influence students' spirit and intensity in following the lesson.

b. External factor (outside factor); It is a spiritual factor consisting of intelligence, behavior, talent, interest, and motivation. It is a factor beyond an individual; in other words, an environment condition around the students. It includes family, school, and social environment. 
c. Learning approach factor; students' activities influence the achievement of good learning outcomes during their learning process. The learning approach means anyways or strategies employed by the students in supporting the effectiveness and efficiency of their learning process.

Similar to Muhibbinsyah, Dalyono in Ahmad Syarifuddin revealed factors influencing learning outcomes such as the learning approach factor included in the internal variable. The complete variables are:

a. Internal factor (from inside): Health, intelligence and talent, interest and motivation, learning method

b. External factor (from outside): Family, School, Society, and Nearby Environment (Ahmad syarifuddin, 2011).

Torin opines a different grouping: 1). Physiological aspects, including the situation or condition of someone's body. The state of particular organs such as the health level of eyes and ears profoundly influences the students' ability to gain information or lesson, 2). Psychological Aspect including students' level of intelligence, behavior, talent, interest, motivation, focus, maturity, and readiness (Tohirin, 2005)

Another reference related to the learning outcome belongs to Djaali in Ahmad Syarifudin. It stated that there are many factors influence learning, namely: 1 . Motivation 2. Behavior 3. Interest 4. Learning habit 5. Self-concept. (Ahmad Syarifuddin, 2011). Okland brought another concept in classifying the determinants of learning outcome into six categories and two manifestations. First, the manifestation of learning process consisting of students' activity, work process, and learning motivation; second, the manifestation of learning content consisting of correction, information from teacher, and putting into context (Økland, 2012)

The research analyzes factors determining the learning outcome of microeconomics theory of Social education students in Teacher and Training Faculty UIN Maulana Malik Ibrahim Malang. It expected that by finding out the factors, it could become one of the references to improve learning outcomes.

\section{[Q] Method}

This research applies descriptive quantitative through Confirmatory Factor Analysis. The questionnaire is used as primary data to obtain the students' responses; they are students of the Social Science department in the academic year 2016/2017. The research instrument covers 25 factors which are drawn by theoretical learning outcome as follow: 
Table 2: Research Instrument

\begin{tabular}{|c|c|c|c|}
\hline \multicolumn{4}{|c|}{ Variable of Learning Outcome, The elements are developed into: } \\
\hline NO & Indicators & No & Developed factors \\
\hline 1 & Health & 14 & Learning habit \\
\hline 2 & Classroom cleanliness & 15 & Learning Style \\
\hline 3 & Learning manner & 16 & Lecturer's explanation \\
\hline 4 & Motivation & 17 & Learning intensity \\
\hline 5 & Course interest & 18 & Sex \\
\hline 6 & Spiritual condition & 19 & Previous experience \\
\hline 7 & Background knowledge & 20 & Age \\
\hline 8 & Teaching method & 21 & Benefit \\
\hline 9 & Recitation & 22 & Course significance \\
\hline 10 & Task weight & 23 & Classroom facility \\
\hline 11 & Intelligence & 24 & Financial condition \\
\hline 12 & Talent & 25 & Friendship \\
\hline 13 & Family support & & \\
\hline
\end{tabular}

\section{Validity and Reliability of the Instrument}

The validity explains that item number 1 (health) and 25 (friendship) omitted since their probability is over 0.05 . The reliability test shows that the use of the questionnaire is reliable in this research since the Cronbach's Alpha value is 0.864 higher than 0.6.

\section{Data Analysis}

The data analysis technique used in this research is factor analysis. It is the study of interdependence between variables to find new sets of variables that are fewer in number than the former variables, which are common factors (Suryanto, 1998). Factor analysis is a mathematical technique that allows the reduction of related variables to a smaller number of dimensions (Kass \& Tinsley, 1979). Factor analysis in this research uses Confirmatory Analysis Model.

Mathematical models of factor analysis as in the following equation:

$$
X_{I}=B_{i 1} F_{1}+B_{i 2} F_{2}+B_{i 3} F_{3}+\cdots+B_{i j} F_{j}+\cdots+B_{i m} F_{m}+V_{I} \mu_{i}
$$

where:

$X_{I}=$ Variable I which is standardized

$B_{i 1}=$ Partial regression coefficient for variable $\mathrm{i}$ on common factor $\mathrm{j}$

$F_{j}=$ Common factor $\mathrm{j}$

$V_{I}=$ Partial regression coefficient for variable I on unique factor $\mathrm{i}$

$\mu_{i}=$ Unique factor of variable $\mathrm{i}$

$m=$ Amount of common factor

Unique factors correlate with common factors; it can be said as the variable investigated, as reflected in the following equation:

$$
F_{i}=W_{i 1} X_{1}+W_{i 2} X_{2}+W_{i 3} X_{3}+\ldots+W_{i k} X_{k}
$$

where:

$F_{i}=$ The factor I which is estimated

$W_{i k}=$ Weight/coefficient of factor score

$X_{k}=$ The amount of factor $X$ on factor $\mathrm{k}$ 
The steps in factor analysis include: 1) KMO test (Keyer Meyer Olkin), used to determine the index to see the accuracy of factor analysis. 2). Bartletts Test of Sphericity used to ensure that Variables do not correlate with each other in the population. This condition will be achieved if the significance value is below 0.05. 3). MSA (Measure of Sampling Adequacy) Test, Index that shows the partial correlation coefficient of each variable, 4) The loading factor is the correlation between the variable and the extraction result factor. The loading element rotated so that each variable correlates sturdily to only one factor.

\section{Result}

\section{KMO Test, Bartlett's Test of Sphericity, MSA, Anti-Image Collection Communalities}

The results of data processing using SPSS show that the KMO test of 0.767 is an index to predict the accuracy of the analysis of uncorrelated factors, and the value of Bartlett's Test of Sphericity 0.000 indicates that the data used in the research did not produce identity matrix.

Anti-Image Correlation shows that the MSA value of 23 variables proposed in the model indicates a value greater than 0.5 , so it is feasible to proceed. Further, extraction values are below 0.5 so that the item excluded because the relationship factor is not sturdy to be used in the model. The resulting communalities value 2 was an extraction value of more than 0.5 .

\begin{tabular}{|c|c|c|c|c|c|c|}
\hline \multirow[t]{2}{*}{ No } & \multirow[t]{2}{*}{ Variables } & \multirow{2}{*}{$\begin{array}{l}\text { Anti-Image } \\
\text { Correlation } \\
\text { MSA }\end{array}$} & \multicolumn{2}{|c|}{ Communalities 1} & \multicolumn{2}{|l|}{ Communalities 2} \\
\hline & & & Initial & Extraction & Initial & Extraction \\
\hline 1 & Classroom cleanliness & 0.691 & 1.000 & .497 & & \\
\hline 2 & Learning manner & 0.878 & 1.000 & .572 & 1.000 & .619 \\
\hline 3 & Motivation & 0.736 & 1.000 & .597 & 1.000 & .646 \\
\hline 4 & Course interest & 0.775 & 1.000 & .588 & 1.000 & .635 \\
\hline 5 & Spiritual condition & 0.639 & 1.000 & .753 & 1.000 & .754 \\
\hline 6 & Background knowledge & 0.772 & 1.000 & .650 & 1.000 & .661 \\
\hline 7 & Teaching method & 0.851 & 1.000 & .638 & 1.000 & .647 \\
\hline 8 & Recitation & 0.681 & 1.000 & .740 & 1.000 & .736 \\
\hline 9 & Task weight & 0.764 & 1.000 & .395 & & \\
\hline 10 & Intelligence & 0.759 & 1.000 & .571 & 1.000 & .619 \\
\hline 11 & Talent & 0.851 & 1.000 & .580 & 1.000 & .646 \\
\hline 12 & Family support & 0.711 & 1.000 & .548 & 1.000 & .635 \\
\hline 13 & Learning habit & 0.720 & 1.000 & .638 & 1.000 & .754 \\
\hline 14 & Learning Style & 0.782 & 1.000 & .677 & 1.000 & .661 \\
\hline 15 & Lecturer's explanation & 0.813 & 1.000 & .593 & 1.000 & .647 \\
\hline 16 & Learning intensity & 0.798 & 1.000 & .567 & 1.000 & .736 \\
\hline 17 & Sex & 0.649 & 1.000 & .692 & 1.000 & .593 \\
\hline 18 & Previous experience & 0.799 & 1.000 & .654 & 1.000 & .583 \\
\hline 19 & Age & 0.648 & 1.000 & .718 & 1.000 & .648 \\
\hline 20 & Benefit & 0.824 & 1.000 & .554 & 1.000 & .667 \\
\hline 21 & Course Significance & 0.852 & 1.000 & .480 & & \\
\hline 22 & Classroom facility & 0.815 & 1.000 & .516 & 1.000 & .501 \\
\hline 23 & Financial condition & 0.638 & 1.000 & .690 & 1.000 & .671 \\
\hline \multicolumn{2}{|c|}{$\begin{array}{l}\text { Kaiser-Meyer-Olkin Measure of Sampling } \\
\text { Adequacy }\end{array}$} & $\begin{array}{l}0.767 \\
0.000\end{array}$ & & & & \\
\hline
\end{tabular}




\section{Total Varian explained}

The result of the Eigenvalue illuminates the relative importance of each factor in calculating the variance of the 20 variables analyzed. The total variance of the 20 variables extracted into seven variables with the following details:

$24.391 \%+9.911 \%+7.300 \%+6.371 \%+6.175 \%,+5.453 \%+5.302 \%=64.903 \%$

The details presented in the following table:

Tabel 12. : Total Variance Explained

\begin{tabular}{|c|c|c|c|c|c|c|c|c|c|}
\hline \multirow{2}{*}{ Component } & \multicolumn{3}{|c|}{ Initial Eigenvalues } & \multicolumn{3}{|c|}{$\begin{array}{l}\text { Extraction Sums of Squared } \\
\text { Loadings }\end{array}$} & \multicolumn{3}{|c|}{$\begin{array}{c}\text { Rotation Sums of Squared } \\
\text { Loadings }\end{array}$} \\
\hline & Total & $\begin{array}{c}\% \text { of } \\
\text { Variance }\end{array}$ & $\begin{array}{c}\text { Cumulative } \\
\%\end{array}$ & Total & $\begin{array}{c}\% \text { of } \\
\text { Variance }\end{array}$ & $\begin{array}{c}\text { Cumulative } \\
\%\end{array}$ & Total & $\begin{array}{c}\% \text { of } \\
\text { Variance }\end{array}$ & $\begin{array}{c}\text { Cumulative } \\
\%\end{array}$ \\
\hline 1 & 4.878 & 24.391 & 24.391 & 4.878 & 24.391 & 24.391 & 2.498 & 12.489 & 12.489 \\
\hline 2 & 1.982 & 9.911 & 34.302 & 1.982 & 9.911 & 34.302 & 2.131 & 10.653 & 23.142 \\
\hline 3 & 1.460 & 7.300 & 41.602 & 1.460 & 7.300 & 41.602 & 2.012 & 10.062 & 33.204 \\
\hline 4 & 1.274 & 6.371 & 47.973 & 1.274 & 6.371 & 47.973 & 1.877 & 9.384 & 42.588 \\
\hline 5 & 1.235 & 6.175 & 54.148 & 1.235 & 6.175 & 54.148 & 1.502 & 7.510 & 50.098 \\
\hline 6 & 1.091 & 5.453 & 59.601 & 1.091 & 5.453 & 59.601 & 1.482 & 7.411 & 57.509 \\
\hline 7 & 1.060 & 5.302 & 64.903 & 1.060 & 5.302 & 64.903 & 1.479 & 7.394 & 64.903 \\
\hline 8 & .874 & 4.372 & 69.275 & & & & & & \\
\hline 9 & .825 & 4.126 & 73.401 & & & & & & \\
\hline 10 & .710 & 3.551 & 76.951 & & & & & & \\
\hline 11 & .665 & 3.323 & 80.274 & & & & & & \\
\hline 12 & .630 & 3.151 & 83.426 & & & & & & \\
\hline 13 & .563 & 2.814 & 86.240 & & & & & & \\
\hline 14 & .543 & 2.716 & 88.956 & & & & & & \\
\hline 15 & .474 & 2.371 & 91.328 & & & & & & \\
\hline 16 & .425 & 2.127 & 93.455 & & & & & & \\
\hline 17 & .393 & 1.967 & 95.422 & & & & & & \\
\hline 18 & .346 & 1.731 & 97.153 & & & & & & \\
\hline 19 & .290 & 1.448 & 98.601 & & & & & & \\
\hline 20 & .280 & 1.399 & 100.000 & & & & & & \\
\hline
\end{tabular}

Extraction Method: PrincipalComponent

Analysis.

The final stage of factor analysis uses the Rotate Component Matrix. The value of the loading factor is the magnitude of the correlation between the factors formed with the notching variables. The results of the rotation of the matrix component presented, then an analysis of grouping is carried out; after that, the process of naming the formation factors done. The name formation of the seven formed elements presented in the following table. 
Table 12 Factor of Notching Variable in the Model

\begin{tabular}{|c|c|c|c|}
\hline No & Name of factors & Proponent factor & Weight \\
\hline \multirow[t]{5}{*}{1} & \multirow{5}{*}{$\begin{array}{l}\text { The ability of } \\
\text { students and } \\
\text { lecturers }\end{array}$} & Background knowledge & .779 \\
\hline & & Teaching method & .672 \\
\hline & & Course interest & .672 \\
\hline & & Learning manner & .630 \\
\hline & & Lecturer's explanation & .561 \\
\hline \multirow[t]{3}{*}{2} & \multirow[t]{3}{*}{ Learning Method } & learning style & .804 \\
\hline & & Learning habit & .720 \\
\hline & & Learning intensity & .623 \\
\hline \multirow[t]{4}{*}{3} & \multirow{4}{*}{$\begin{array}{l}\text { Students' initial } \\
\text { modal }\end{array}$} & Previous experience & .741 \\
\hline & & Talent & .635 \\
\hline & & Benefit & .601 \\
\hline & & Intelligence & .546 \\
\hline \multirow[t]{2}{*}{4} & \multirow[t]{2}{*}{ Readiness } & Sex & .819 \\
\hline & & Age & .809 \\
\hline \multirow[t]{2}{*}{5} & \multirow[t]{2}{*}{ Facility } & Classroom facility & .611 \\
\hline & & Financial condition & .579 \\
\hline \multirow[t]{2}{*}{6} & \multirow[t]{2}{*}{ Psychology } & Spiritual condition & .795 \\
\hline & & Family support & .644 \\
\hline \multirow[t]{2}{*}{7} & \multirow[t]{2}{*}{ Learning drive } & Recitation & .825 \\
\hline & & Motivation & .638 \\
\hline
\end{tabular}

\section{i Discussion}

\section{Students' and lecturers' Ability Factor}

Mathematically, the first factor can be formulated $F_{1}=0.779 X_{1}+0.672 X_{2}+0.672 X_{3}+0.630 X_{4}+0.561 X_{5}$. The contributions made by the first-factor formula are background knowledge $\left(X_{1}\right)$, teaching method $\left(X_{2}\right)$, course interest $\left(X_{3}\right)$, learning manner $\left(X_{4}\right)$, lecturer's explanation $\left(X_{5}\right)$.

This result indicates that the students' and the lecturers' ability may affect the students' learning results. The background of knowledge creates this factor. When the students have already gained specific experience about the subject that will be discussed, the possibility that they can increase their learning result gets higher and vice versa. The second shaping factor is the lecturers' method. The better the technique used, the better the learning result will possibly be, and vice versa. Kapur states that teachers have a vital role in guiding and managing the class activities since teachers can affect the students' academic performance (Kapur, 2018). The third shaping factor is course interest. It cannot be denied that students' attention will determine students' or lecturers' abilities since we have a will and effort to study a specific topic when we are interested in it. For example, when a student says that he/she is interested in microeconomy theory, then he/she will work hard to obtain a maximum score. The other indicator is related to a learning manner. It is natural to have students find the right way of studying because it will be easier for them to increase their learning results if they can successfully find out the best way of studying. The last and very crucial indicator in supporting lecturers' and students' abilities is the lecturer's explanation in conveying the materials. This explanation of 
lecturers becomes the principal tool of knowledge transferring process to the students because the process of knowledge transfer can be considered successful when the lecturers possess the ability to convey the lesson materials.

\section{Learning Method}

In Mathematics, the second factor can be formulated into $\mathrm{F}_{1}=0.804 \mathrm{X}_{1}+0.720 \mathrm{X}_{2}+$ $0.623 X_{3}$. The contributions made by the second factor are the students' learning style $\left(X_{1}\right)$, learning habit $\left(X_{2}\right)$, and learning intensity $\left(X_{3}\right)$.

The first supporting factor is the learning style. If students have found the right method, they can increase their interest in studying the materials that they have discussed. For instance, if a student knows that he/she is a visual learner type, he/she will make an exciting summary to study microeconomy theory. The same goes for auditory or kinesthetic learners; they will use a different method for studying. The second supporting factor is the learning habit. This factor may be able to predict students' learning patterns. If a student implements a specific model such as sparing a certain amount of time every day to study the main discussion of Economics that will be covered in the class, then his ability to master the materials will get better. It is different from students who have no habit of studying. The third supporting factor is learning intensity, which indicates that the more frequent we consider, the higher the learning outcome will improve - the third supporting factor in determining concentration. The more frequent a student learns, then higher the learning outcome will improve. The more frequent a student learns about the microeconomy, the higher the learning outcome they will achieve.

\section{Students' Initial Modal}

Mathematically, the third factor can be formulated into $F_{1}=0.741 X_{1}+0.635 X_{2}+$ $0.601 \mathrm{X}_{3}+0.546 \mathrm{X}_{3}$. The contributions made by the third factor are the previous experience $\left(X_{1}\right)$, talent $\left(X_{2}\right)$, benefits $\left(X_{3}\right)$, and intelligence $\left(X_{4}\right)$. The first supporting factor is the previous experience. If a student has learned something before coming to the class, then his/her ability to retrieve lessons will increase so that the learning outcome can also be increased. The second supporting factor is talent. If someone, for instance, has a talent in mastering a social subject, then he/she will understand the material even more in the future, and the learning outcome will improve. The third supporting factor is the benefit. If the benefit that will be gained by the students gets higher or bigger, then students will not let go of a chance to get the benefit. The last supporting factor is intelligence; the higher the intelligence, the higher the learning outcome that will achieve.

\section{Readiness}

Mathematically, the fourth factor can be formulated $F_{1}=0.819 X_{1}+0.809 X_{2}$. The contributions made by sex $\left(X_{1}\right)$ and age $\left(X_{2}\right)$. The first supporting factor of gender relates to the characteristics of the microeconomy theory subject since this subject needs perseverance and accuracy. In this case, the female will probably tend to dominate if the 
improvement of learning outcome is the goal. The second supporting factor is age. The more mature the period, the better the ability to absorb the material so that the learning outcome will also improve. Hansen explains that student performance depends on several factors, such as learning facilities and age differences.(Mushtaq \& Khan, 2012)

\section{Facilities}

Mathematically, the fifth factor can be formulated $F_{1}=0.611 X_{1}+0.579 X_{2}$. The contributions of the fifth factor are classroom facilities $\left(X_{1}\right)$ and financial condition $\left(X_{2}\right)$. The first supporting factor is classroom facilities; that is why demands regarding class facilities must be fulfilled. Everything from the availability of chairs, the comfort of chairs, the cleanliness of class, and the eligibility of LCD must be looked after so that the teaching and learning process can be improved, and it will result in a maximum learning outcome. It is in line with Mushtaq's and Khan's findings that learning facilities will affect academic performance (Mushtaq \& Khan, 2012). The second supporting factor is the financial condition. Financial condition will support the availability of books and supporting tools in a class activity; thus, the better the financial situation someone has, the better his/her learning outcome will be. In his research, Kapur mentioned poverty as an obstacle to academic achievement. (Kapur, 2018)

\section{Psychology}

Mathematically, the sixth factor can be formulated $F_{1}=0.795 X_{1}+0.644 X_{2}$. The contributions of the sixth factor made our spiritual condition $\left(X_{1}\right)$ and family support $\left(X_{2}\right)$. The first supporting factor is the mental condition. Someone whose mental health is goodwill has a healthy brain so that his/her thinking skill improved, and the learning outcome will eventually be improved. The second supporting factor is family support. A harmonious family will create a healthy climate for the whole family members. It can enhance the learning outcome through the improvement of learning motivation. Kapur states that parents' role is very crucial to boost the learning atmosphere at home, so the academic achievement will also increase(Kapur, 2018)

\section{Learning Drive}

Mathematically, the second factor can be formulated $F_{1}=0.825 X_{1}+0.638 X_{2}$. The contribution of the seventh factor is recitation $\left(X_{1}\right)$ and motivation $\left(X_{2}\right)$. The seventh factor influencing the learning outcome is learning drive. It reflected through the amount of one's effort to do recitation and how motivated he/she is to learn a particular subject.

\section{第 Conclusion}

Seven formed factors affect students' learning outcome on Economics Subject, namely: (1) Students' and lecturers' skill, which developed from the background knowledge, teaching method, course interest, learning manner, lecturer's explanation; (2) Learning method, which formed from three-factor named learning style, learning habit, 
and learning intensity; (3) Students' initial modal, which developed from some element such as previous experience, talent, benefit, and intelligence; (4) Readiness, which formed from two variables, namely sex and age; (5) Facilities which created from two variables; those are classroom facilities and financial condition; (6) Psychology which developed from the spiritual health and family support; (7) Learning drives that created from recitation and motivation.

\section{Bibliography}

Adam, S. (2004). Using the Learning Outcome. Edinburgh Conference Centre, Scotland, 30.

Ahmad syarifuddin. (2011). Penerapan Model Pembelajaran Cooperative Belajar Dan FaktorFaktor Yang Mempengaruhinya. Ta'dib Jurnal Pendidikan Islam, Vol XVI, No. 01 Juni 2011, 113-136.

Hattie, J.A.C. (2009). Visible learning: A synthesis of over 800 meta-analyses relating to achievement. Routledge.

Kapur, D. R. (2018). Factors Influencing the Student's Academic Performance in Secondary Schools in India. Researchgate, 25.

(https://www.researchgate.net/publication/324819919).

Kurniawan, B., Wiharna, O., \& Permana, T. (2017). Studi Analisis Faktor-Faktor Yang Mempengaruhi Hasil Belajar Pada Mata Pelajaran Teknik Listrik Dasar Otomotif. Journal of Mechanical Engineering Education, Vol. 4, No. 2, December 2017, 156-162. https:// doi.org/10.17509/jmee.v4i2.9627

Lin, J.-W. (2016). Examining the Factors That Influence Students' Science Learning Processes and Their Learning Outcomes: 30 Years of Conceptual Change Research. EURASIA Journal of Mathematics, Science \& Technology Education, 12(10). https:/ / doi.org/10.12973/eurasia.2016.000600a

Muhibbin Syah. (2017). Psikologi Pendidikan dengan Pendekatan Baru Edisi Revisi (22nd ed.). Bandung: PT Remaja Rosdakarya.

Mushtaq, I., \& Khan, S. N. (2012). Factors Affecting Students' Academic Performance. 7.

Økland, G. M. (2012). Determinants of Learning Outcome for Students at High School in Norway: A Constructivist Approach. Scandinavian Journal of Educational Research, 56(2), 119-138. https://doi.org/10.1080/00313831.2011.568622

Pusposari, L. F. (2017). Pengaruh Gaya Belajar Mahasiswa Terhadap Hasil Belajar Pada Matakuliah Teori Ekonomi Mikro Jurusan PIPS Uin Maulana Malik Ibrahim Malang. JPIPS, 3 Nomer 2 Tahun 2017. https:/ / doi.org/DOI: http://dx.doi.org/10.18860/jpips.v3i2.6861

Sutrisno, V. L. P., \& Siswanto, B. T. (2016). Faktor-faktor yang mempengaruhi hasil belajar siswa pada pembelajaran praktik kelistrikan otomotif SMK di Kota Yogyakarta. Jurnal Pendidikan Vokasi, 6(1), 111-120. https:/ / doi.org/10.21831/jpv.v6i1.8118

TIM FITK. (2018). Pedoman Pendidikan. Malang: FITK UIN MALANG.

Tohirin. (2005). Psikologi Pembelajaran Agama Islam. Jakarta: Raja Grafindo Persada.

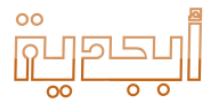

